Relations industrielles

Industrial Relations

\title{
Sengenberger, Werner, and Duncan Campbell, editors, Creating Economic Opportunities: The Role of Labour Standards in Industrial Restructuring
}

\section{Maurice Mazerolle}

Volume 50, numéro 3, 1995

URI : https://id.erudit.org/iderudit/051047ar

DOI : https://doi.org/10.7202/051047ar

Aller au sommaire du numéro

Éditeur(s)

Département des relations industrielles de l'Université Laval

ISSN

0034-379X (imprimé)

1703-8138 (numérique)

Découvrir la revue

Citer ce compte rendu

Mazerolle, M. (1995). Compte rendu de [Sengenberger, Werner, and Duncan Campbell, editors, Creating Economic Opportunities: The Role of Labour Standards in Industrial Restructuring]. Relations industrielles / Industrial Relations, 50(3), 675-677. https://doi.org/10.7202/051047ar

Tous droits réservés (C) Département des relations industrielles de l'Université Laval, 1995
Ce document est protégé par la loi sur le droit d'auteur. L'utilisation des services d'Érudit (y compris la reproduction) est assujettie à sa politique d'utilisation que vous pouvez consulter en ligne.

https://apropos.erudit.org/fr/usagers/politique-dutilisation/ 
façon plus stimulante. Pourtant, il est clair que, même avec ces biais, ce livre comble un lacune ressentie depuis longtemps au Québec et ouvre de nombreuses voies de recherche en la matière et $\mathrm{ce}$, dans un contexte canadien où des débats restent toujours très animés sur le rôle de l'immigration et sur les contributions économiques des immigrés par rapport aux coûts engendrés pour le pays.

ZHAN SU

Université Laval

\section{Creating Economic Opportunities: The Role of Labour Standards in Industrial Restructuring}

edited by Werner SENGENBERGER and Duncan CAMPBELL, Geneva, International Institute for Labour Studies, 1994, 439 p., ISBN 92-9014-529-3 (pbk.).

While the popular and business presses seem single-minded in their portrayal of labour standards and their accompanying regulations as an obstacle to the efficient workings of the labour market, the academic community and policy-makers are divided in their perceptions and views as to whether labour standards constitute a help or hindrance to the process of industrial change and economic modernization or transformation. This debate currently suffers from at least two shortcomings. One is that the arguments for and against the economic rationality of standards are insufficiently spelled out. What is it exactly that makes standards promote and lubricate or hamper and retard adjustment? The other shortcoming is a dearth of empirical knowledge on what the actual effects of standards are for the process and economic outcome of restructuring.

To help redress this situation the International Institute for Labour Studies under its "Labour Institutions and New Industrial Organization" programme in collaboration with the European Trade Union Institute in Brussels established a working group in 1988 with the objectives of furthering conceptual work and empirical studies that would shed light on the role and value of labour standards. This volume is an attempt to lay out the case for and against labour standards in relation to economic performance.
However, one should not be under the perception that they will find a raging debate within this book since both the sponsors and contributors are advocates of using labour standards as a means of ending the vicious cycle of low wage competition. However, this is not a criticism. It was quite refreshing to read a book that seems positively iconoclastic in its views given the unrelenting onslaught against regulation of any kind, never mind an expanded role for the state.

Labour standards are viewed as a means of accommodating interests between groups of workers, firms, regions, and countries, with the key objective of preventing destructive competition in the labour market based on low or the lowering of wages and other terms of employment. In essence, the availability of undervalued labour as a result of no or inadequate labour standards is portrayed as not being conducive to productive efficiency because it provides a way of compensation for managerial, organizational, and other forms of inadequacies, delays the scraping of obsolete capital equipment and allows for price competition based on lowering wage costs. In other words, labour standards are seen as a means to bar certain possibilities of action viewed as socially damaging in order to open up and actively promote socially acceptable options for adjustment. Success in the 
long-term it is felt, depends on product rather than price competition. This will require an emphasis on research and development, product design and quality, strategies which are unlikely to be compatible with the exploitation of undervalued labour.

Three different categories of standards are distinguished; standards of protection, participation, and promotion. The function of protective standards is essentially to foreclose particular options of adjustment which are regarded as socially undesirable. The principal means are legal and contractual norms that either prescribe or rule out certain action or conduct. Promotive standards by contrast are instruments which are designed to elicit or support policies and actions regarded as desirable. Monetary and institutional incentives are the main tools for that. Standards of participation refer to the sharing of information, joint decision making, joint consultation, and control among workers, employers, and government. Standards of participation give legitimacy to the setting and control of rules and regulation. By actively involving people in restructuring processes standards of participation improve the intelligence experience and creativity of the scope and means of restructuring. All three types of standards must be in place in order to transform a vicious cycle of low wage competition into a virtuous cycle of product competition.

This volume is divided into four parts. Part one is really the introductory chapter which portrays the whole range of labour standards as an institutional framework for restructuring and development. Part two looks at the types of labour standards that are usually found within industrialized countries. This part contains four chapters that look at protection, participation, and promotion aspects of labour standards, the case for universally applied equitable standards for wages and conditions of work, employment protection and security, and the regional impact of unemployment insurance and active labour market policy by looking at an international comparison of Germany, Austria, the United States, and Britain. Part three looks at the impact of standards at various levels of organization, and contains seven chapters. There is a chapter on company level internal restructuring and retraining within West and East Germany, another chapter on industry level restructuring by presenting the cases of the shipbuilding industry in Germany and Sweden. Restructuring at the regional level is presented through four case studies. South Bend, Indiana is presented as an example of regional restructuring without labour union participation and the removal of many labour standards. In case two an argument is presented for changing the industrial relations system in the province of Ontario in order for the parties to freely negotiate the terms and conditions necessary for positive restructuring to take place. Case three looks at the role of labour standards and economic reconversion of the iron and steel producing industries in Lorraine France. The fourth case looks at the role of labour standards and the achievement of flexible industrialization within the region of Emilia-Romagna, Italy. Restructuring at the national level is presented in a chapter on labour-led restructuring and reform in Australia, while another chapter looks at restructuring at the European Community level, by looking at the push for a social charter and the creative tension that market forces play in the move toward integration. There is also a chapter that discusses the role of international labour standards in restructuring at the global level. Finally, a concluding chapter tries to sort out some of the lessons learned from experience with industrial restructuring.

Have the editors and the contributing authors succeeded in their original quest of spelling out exactly what makes standards promote and lubricate or hamper and retard adjustment? Have they con- 
tributed to the empirical knowledge as to the actual effects of standards on the process and economic outcome of restructuring? Of the two objectives, I would say that they were more successful in accomplishing the second objective. However, there is no question that this book should prove useful to those who are looking for both the evidence and the rationale for a greater role of the state in the intelligent use of labour standards as a means to channel market forces toward socially desirable directions.

MAURICE MAZEROLLE Toronto, Ontario

\section{Shadows of the Mind: A Search for the Missing Science of Consciousness} by Roger PENROSE, Oxford, Angleterre, Oxford University Press, 1994, xvi+457 p. ISBN 0-19-853978-9.

\section{La conscience chez l'ordinateur}

L'ordinateur aura-til une conscience? Pourra-t-il penser? Sera-t-il intelligent? Bref, le domaine de l'intelligence artificielle (IA) a-t-il un avenir? Le récent livre du physicien anglais Roger Penrose communique un message qui est le prolongement de son précédent, L'esprit, l'ordinateur et les lois de la physique (Paris, InterÉditions, 1992), dans lequel il maintenait que jamais un ordinateur ne sera conscient, donc jamais véritablement intelligent. Dans Shadows of the Mind. A Search for the Missing Science of Consciousness, l'auteur explique que notre "mentalité consciente " et ses diverses manifestations ne seront jamais comprises par des modèles fondés sur des calculs.

\section{À la recherche d'une physique nouvelle}

Il y a deux parties au récent livre. À la partie I (trois chapitres), Penrose réfère à un "ingrédient " absent de la façon de voir les choses scientifiquement. Selon lui, il n'existe pas encore de théories physique, biologique et de calcul qui permettent d'expliquer notre conscience et, par conséquent, notre intelligence. L'ordinateur de l'avenir aurat-il un esprit? En guise de réponse à ce genre de questions, l'auteur propose, dès le premier chapitre, quatre options (p. 12):

A- Toute pensée est fondée sur le calcul ; les sentiments d'être conscient sont évoqués simplement en réalisant les calculs appropriés.

B- Etre conscient est une caractéristique de l'action physique du cerveau; alors que toute action physique peut être simulée par des calculs, la simulation par calculs seule ne peut pas rendre conscient.

C- L'action appropriée du cerveau rend conscient, mais cette action physique ne peut même pas être convenablement simulée par des calculs.

D- Etre conscient ne s'explique pas en des termes physiques, ni de calculs, ni en d'autres termes scientifiques.

L'option A est celle des défenseurs d'une IA qualifiée de "forte". Ceux-ci maintiennent qu'il est possible de simuler la conscience en ordinateur par des calculs et alors le rendre conscient. L'option B est celle de l'IA qualifiée de "faible". Si ses partisans reconnaissent la possibilité de simuler par des calculs la conscience, ils conviennent que l'ordinateur en cause ne sera pas conscient pour autant. Quant à l'option D, elle est celle du mysticisme, des doctrines religieuses. L'auteur démolit ces trois options et retient l'option $\mathrm{C}$ où il reconnaît que les questions reliées à l'esprit ne doivent pas se situer éternellement à l'extérieur des domaines scientifiques. Il signale qu'un atout de l'option C est son ouverture sur de futures réalisations scientifiques qui permettraient la construction d'appareils fondés sur des actions 